\title{
Projection and Time in Proclus
}

D. Gregory MacIsaac

\section{Introduction}

This chapter is an examination of certain parts of the philosophy of Proclus. Its aim is to clarify in what manner Proclus is a systematic thinker. The notion of philosophical system which comes to mind from a contemporary standpoint is not the notion which Proclus had, and any interpretation of Proclus from a later standpoint is bound to fail. Proclus' notion of philosophical system, moreover, is important for the interpretation of all medieval philosophy, because the Greek Neoplatonic tradition of which he is a part contributed to the self-understanding of Medieval Jewish, Islamic, and Christian thinkers. ${ }^{1}$ His notion of philosophical system helps to clarify such medieval principles as the distinction between kataphatic and apophatic theology, the difference between human and divine knowing, and the analogy of Being. If we investigate Medieval philosophy with a conception of philosophical system drawn from a later period, these aspects of Medieval thought will remain closed to us.

The philosophy of Proclus is philosophy as system. ${ }^{2}$ The whole of Being, as well as what lies above and below Being, is articulated in determinate rational categories in his various works. The Cosmos which springs from the One, and unfolds into Nous (Intellect), Soul, and Material World is discussed in human terms in his commentaries on Plato's Cratylus, Alcibiades, Republic, Timaeus and Parmenides. Mathematical and physical being is discussed in his commentary on Euclid and his Elements of Physics. Providence, fate and evil are treated in three short works. And finally, we have two explicitly systematic works, the Elements of Theology and the Platonic Theology, the former of which lays out the structure of the cosmos from the One to the Soul, and the latter of which lays out the structure of the divine orders. The breadth of this corpus suggests that according to Proclus there is nothing which is not open to human thought. 
We should find this systematic character of Proclus' thought puzzling. He thinks that a philosophical text is logos. It is the written expression of a human thinking which itself is also logos. And according to Proclus human thinking belongs in a middle register. It is dianoia, and dwells in the thinking belongs in-between. Although it is neither the infinite multiplicity of sensation, nor the pregnant unity of intellect, it is somehow still able to think both. ${ }^{3}$ And it does this without leaving aside the sort of thought which is specifically human. The soul comprehends the unity of intellect through its own dividing activity, and comprehends sensibles without entering into their sort of division (Proclus, In Euclidem 16). Consequently, if we are to understand Proclus' philosophy as a system which comprehends the entire cosmos, we must understand this comprehension in a manner which does not do away with the real otherness of the being and knowing which lies above and below the soul. This is the puzzle which we will investigate in this chapter. below the soul. This is the puzzle which we will investigate in this cheicheiôs Theologike as Systematic Ground of the Cosmos, leads us to believe that all is contained in principle in this one work of Proclus. The Elements of Theology, he tells us, seeks "to give a complete account of the ground and nature of phenomena and of the cause of those phenomena or of the nature of that ground" (Lowry 1980, 37). As a logic of remaining, proceeding, and returning, "its formal structure seeks to be a totality, to be self complete, to be fully comprehensive of all phenomenal possibility as effect and of al ground of phenomena as cause" (Lowry 1980, 38). Unfortunately, according to Lowry, the Procline system in the Elements of Theology succumbs to an inner tension. Proclus' quantitative logic of unity and multiplicity is not adequate to its content as that which grounds the qualitative determinations of Being. Consequently, what is needed is a logic more adequate to its content; a first principle which is not beyond thought; indeed a first principle which is thought itself. ${ }^{4}$ Lowry's reading of Proclus is in Hegelian. The Hegelian reading of Proclus seizes on the Elements of Theology and declares Proclus to be a systematic thinker in this sense, that he would consider his philosophy successful if it were able to give in a work like the Elements of Theology a complete account of the principles of the cosmos. But this focus on completion, even formal completion, is a misreading of Proclus. It ignores the fact that for Proclus philosophical system is expressed in dianoetic terms. Thus while Proclus is a systematic thinker, the terms in which his system is written themselves fall short of the reality which they seek to express. Moreover, because dianoia is a thinking which never has a complete grasp on its object, the Procline system must be considered to be in principle incomplete. I will argue for this account of philosophical system in Proclus in the rest of this chapter, through an examination of Eternity and Time in his philosophy.

However, as a preliminary taste of my conclusion, I ask the reader to reflect on the Procline corpus as I listed it above. If Proclus' philosophy were system as complete, why are there two systematic works? When in possession of the Elements of Theology, what need have we for the Platonic Theology, or vice versa? Lowry admits that the Platonic Theology complements the Elements of Theology, but says that "the Elements of Theology works out most fully the principles of the cosmos, while the Platonic Theology works out their elaboration in the fullest way. Together they give a complete exposition of the Procline philosophy. In fact, it should be said, in my opinion, that together they are the Procline philosophy" (Lowry 1980, 105). But there are discrepancies between the two works, and Lowry's account rests on his characterisation of the henads as the genera of Being. ${ }^{5}$ This is not only contrary to Proclus' explicit doctrine, it does not work as a re-interpretation of Proclus (Lowry 1980, 77). Further, why comment on Plato? With the embarrassing superabundance of riches embodied in not one, but two, 'complete' systems, the other works would have to be written off as merely opportunities for extended digression. Moreover, what is to be made of the tension between the accounts of human reason given in the Euclid commentary and the Parmenides commentary? If not in open conflict, there is certainly a marked difference in emphasis between the mathematical reason of the one, and the ultimate apophasis of the other. Proclus is not an exploratory thinker like Plotinus, who seems to have been torn between various accounts of the same phenomenon. Proclus' various works do not represent conflicting and competing attempts to articulate a system which would complete in the manner in which Lowry wants it to be. Rather, they are an embodiment of his conception of dianoia itself. Dianoia does know the truth of what exists, and it knows it through its own divided categories. But as dianoia is a dividing activity, its knowledge is itself divided. It is also partial, and this partiality arises because its circling activity around its unified object, which is Nous itself, is never complete. Consequently, we can think of the various works of Proclus as articulations of Nous from the various different but complementary perspectives which the soul assumes as it circles around the centre which is Nous. As the regions of Being can be infinitely plumbed by such a dividing thinking, we should expect works which have as their aim to plumb a particular region, such as the Alcibiades or Cratylus commentaries. As this circling, dividing, thinking activity is never complete on the psychic level, we should not attribute the sort of completion to it which Lowry seems to desire.

\section{Eternity}

In the Timaeus Plato tells us that the model (paradeigma) after which the Demiurge made the all (tode to pan) is an Eternal Living Creature (zôon aidion on), and that he made this all more similar (homoion) to its model through the fabrication of Time: 
And as the nature of the Living Creature was to be eternal, it was impossible to bind this nature in its entirety to becoming (tôi gennêtôi). So he planned to make a certain moving image of Eternity (eikô ... kinêton tina aiônos), and then in setting the Heavens in order, he made of that Eternity which remains in a One an eternal image, which proceeds according to number. And it is this image which we call Time (chronon). (Plato, Timaeus 37d)

Proclus comments on this passage at length in the In Timaeum (Proclus, In Timaeum III.8.18-34.14). Proclus gives an account in which Eternity is the principle which unifies the intelligible genera, while Time as its image is the intellectual principle which unifies the dividing activity of Soul, as well as all else which shares in becoming.

Eternity dwells in the intelligible. But where in the intelligible does it reside? Proclus asks in what order (taxis) of the intelligibles (noêta) it exists (Proclus, In Timaeum III.10.02-07). In order to understand this question, we must examine briefly the structure of Proclus' spiritual hierarchy. In Proclus the divisions which emerged in the Plotinian Nous have been systematically related to each other through a logic of unity and multiplicity. Plotinus speaks about a division between subject and object in Nous, and about a multiplicity of genera of Being in Nous, while also asserting the unity of Nous. Proclus also holds to the unity of Nous, but he subjects the reality which is Nous to a dividing analysis, in order to distinguish more clearly its moments. It is crucial to remember about this analysis that the terms through which we understand Nous are not themselves noetic. Our thought is dianoetic, and as such the simultaneous division and unity which is Nous cannot be expressed by us adequately. We can hold only to one side or the other, and we finally fall back on a mode of expression by which we say Nous is a thinking which is both completely unified and divided, even though this is not something we experience in our own thinking.

Proclus refers to the distinction between object and subject in Nous as a division between intelligible (noêta) and intellectual (noera) orders of Nous. Further, between the intelligible and the intellectual is an intermediate order which is referred to as intelligible-and-intellectual (noêta kai noera). This distinction between orders is at first misleading, because it gives one the impression that the intelligible orders are merely object of thought without the activity of thinking, while the intellectual orders are merely activity which looks up to the intelligible for its object. This is not the case. Nous is an hypostasis, which means for Proclus that it is a mind that is a unity in plurality, in which the total structure is mirrored in each part (Gersh 1973, 19ff; 51-58). Similarly, Nous is one mind, but at the same time each of its parts is a reflection of the whole and thus are also individual minds. Thus all of the orders have these three moments in them in some manner, and their hierarchical arrangement is a matter of emphasis. The intelligible has more the character of cause, and thus Proclus distinguishes out three intelligible triads which stand above and give rise to the other orders. Next there come to be three intelligible-and-intellectual triads, ${ }^{6}$ and after these comes an intellectual hebdomad. ${ }^{7}$ So while Nous as a whole is a unity, its various moments as intelligible, intelligible-and-intellectual, and intellectual are to be thought of both as an articulation of the interior nature of the thought of Nous as a whole, and as an articulation of the noes (intellects) which make up the different orders of Nous, all without losing the unity which Nous has as the unity of a thinking mind.

So Proclus' question about the place of Eternity is important. If Eternity is in Nous, and in one of the three intelligible orders of Nous rather than in the lower orders, then it is important to specify exactly which intelligible triad it is. In other words, asking about the place of Eternity in the intelligible is asking what role Eternity plays in the unfolding of the One into the multiplicity of intelligible eidê which found the subsequent diversity of the cosmos. Proclus thinks that the three intelligible triads in Nous are, in order, the One-Being, Eternity, and the Eternal Living Being, or autozôon. The final intelligible triad, the autozôn, is the paradigm to which the Demiurge (who is in the intellectual hebdomad) looks when he orders the cosmos. As such, it contains all of the genera of Being, but in a manner best described by Plotinus, where all is in each and each in all, without any mixture or confusion (Plotinus, Ennead V 8.4). One may be tempted to think of this multiplicity of intelligible genera as a static set of categories. Perhaps they are the five Greatest Kinds (megista genê) of Plato's Sophist. Proclus does speak of them at times in these terms. ${ }^{8}$ Yet it is not the case that a static set of intelligible categories can easily be thought of as all in each and each in all. The dynamism of the Plotinian Nous seems to rule out a conception of the first multiplicity of Being along Aristotelian or Kantian lines, from the Categories or the Critique of Pure Reason. The Plotinian eidê are alive. It is as proper to speak of them as gods as it is to speak of them as the primary division of Being. And they are Being as thought, and thought as the activity (energeia) of thought. They are Being as thinking activity.

If this is the case then the intelligible order of Nous cannot merely contain the autozôon. Proclus has analysed the thinking of Nous into its moments, one of which is the multiplicity of intelligible genera which is the autozôn. But just as there is more to the description of Nous in Plotinus than its multiplicity, so in Proclus this multiplicity must be embraced by and be an expression of a prior unity. The unity here is Eternity as the second intelligible triad. As such Eternity is not a genus of Being, because the genera of Being only make their appearance with the autozôn. Proclus remarks that the genera of Being imply their opposites, but Eternity is not opposed to any of the genera in the way in which Rest, for example, is opposed to Motion. 
All of these are equally eternal: Same, Different, Rest, Motion. This would not be the case if Eternity were one [genus of Being] among them. For Rest is not equally Rest and Motion, but all of the intelligibles are equally always in existence and eternal. So Eternity is opposed to none of these, nor to anything which comes after it. (Proclus, In Timaeum III.11.23-28)

If this is the case, then neither is Time opposed to Eternity. Rather than being the opposite of Eternity, Time is its image. This is important for Proclus' conception of the structure of the whole of things. Being does not fall into two different genera: that which is eternal and that which is temporal. If this were the case, then the eternal and the temporal would be related to each other in the same manner as any other two genera into which Being falls, such as Rest and Motion, or Sameness and Rest. Instead, in Proclus, we find that the temporal is related to the eternal not as simply other than it, but rather as its image. As we will see below, this means that Time is the unifying principle of the temporal, and is not ranked itself as being in Time, in the way that Eternity is the unifying principle of the intelligible genera without itself being one of these genera. Further, eternal things and temporal things are not related as simply belonging to different genera of Being. Rather, temporal things are an image of the eternal genera of Being itself.

So Eternity cannot be a genus of Being, and if it is not a genus of Being it cannot be in the autozôon, the third intelligible triad. Rather, it is the comprehensive principle of the intelligible genera in the autozôn. It is Eternity which brings them to birth and is the cause of their unchanging permanence.

$\ldots$ and [Eternity is] the cause of the unchanging permanence of all [the intelligible genera], a cause which is neither among the many intelligible [genera] themselves, nor comes from them by [a sort of] collection, but is raised above them and present to them, and by itself arranges them and as it were gives them shape, and it does this by making them to be as a whole all at once. For the manifold Form of the intelligibles (hê pantodapê tôn noêtôn idea) is not brought forth immediately after the Good, which is without any trace of multiplicity.

Rather, there are certain natures in between, more unified than the multiplicity of the All-Complete [i.e. the autozôn], and shewing forth in themselves the pangs of childbirth and the signs of the generation of the Wholes and the unifying bond. (Proclus, In Timaeum III.12.18-27)

Eternity is one of these natures that are "in between," as the principle immediately prior to the autozôon. The term "pangs of childbirth" (ôdina) is an interesting term for Proclus to use with regard to the emergence of the intelligible genera from Eternity. Throughout Proclus we find that multiplicity is brought forth from unity. Hence Eternity, as the principle of bringing forth, is not ranked with the intelligible genera, precisely because it is a prior unity which brings them forth. Proclus quotes the Chaldaean Oracles, and takes up their motif of the "Paternal Nous" (patrikos nous) and the "Flower of Nous" (noou anthos).

[Eternity] is saturated (diakorê) with Paternal Divinity, which [the Oracles] call "the Flower of Nous." It shines down on all things, as the source of their nous and their eternally unchanging knowing, and their erotic turning towards (strephesthai) and activity around the cause of all. (Proclus, In Timaeum III.14.11-14)

Eternity is not only the source of the bringing to birth of the intelligible genera, it also is the source of their nous and hence of their circular movement back towards the source of their birth. These two motifs, of paternity and of a turning towards or return (epistrophê) indicate what is really going on in Proclus' conception of Nous. The multiplicity of intelligible genera in the autozôon are not merely a static set of categories, because they themselves are living eidê which have been brought to birth. And in their being brought to birth they look back to their source, they strive towards it erotically, and they attain its unity and perfection in the only way they can, i.e. through their own multiplicity. Nous as a whole has the unity of a mind whose thought is of itself. Nous as intellectual, or as act of thinking, has a unity afforded through its orientation back towards the intelligible genera. But these genera themselves also have the unity afforded by their erotic orientation towards their own source. This unity afforded by being oriented towards a prior unity will also be the sort of unity which Time affords the multiplicity inherent in dianoia.

So in Proclus' system, even at the highest levels of Nous, Being is a dynamic coming forth into multiplicity of that which is hidden in a prior unity. ${ }^{9}$ So that which emerges into multiplicity has a certain unity about it, as having sprung from a single source and as returning to the same source. Such a multiplicity may be thought of as vectoral, i.e. as pointing the way back towards its own origin. Or it may be thought of as the circumference of a circle, whose infinity of points are all made into one figure by their orientation towards the centre, i.e. by their equidistance from the centre.

Nous as a dynamic coming forth of a prior unity into multiplicity is not so much like the common sense which gives unity to the proper senses, in Aristotle, or the transcendental unity of apperception which allows us to add the 'I think' to all of our thoughts, in Kant. Rather, it is in fact closer to the self-articulation of Geist in Hegel, or the revealing of itself of Being in Heidegger. In both these thinkers we have a coming forth into multiplicity, but both differ from Proclus' conception of a unity which is prior to and aloof from the unity it engenders, and which also does emerge into this 
multiplicity. Nous gives rise to a multiplicity of intelligible genera, but it is a primal unity before actualising itself in these multiple ways. Being is itself a power, a unity, which expresses itself in the multiplicity which it brings to birth, yet all that multiplicity of thought which is brought to birth seeks the unity which Being in itself is. ${ }^{10}$ Thus besides the third intelligible triad, the autozôn which is the multiplicity of intelligible genera, there must be a prior principle which brings this multiplicity to birth. And this is Eternity, the second intelligible triad.

Let us concede that there must be a principle before the autozôon. Why is it Eternity, and why is there also another intelligible triad before Eternity? Briefly stated, Proclus tells us that from Plato we know that the autozôon is eternal. But to be eternal means to participate in Eternity, not to be Eternity itself. So we know that Eternity is distinct from, and higher than, the autozôon. Further, by analogy with Time and the World, we know that Eternity is the next thing above the autozôon. Proclus tells us that the World is the first thing to participate in Time, because Time did not exist before the creation of the World (Proclus, In Timaeum III.12.31ff). In other words, genesis as a whole participates in Time as a whole, and is its primary participant. Likewise, the totality of intelligible genera participate in Eternity as a whole, and is its primary participant, because it is the primary locus of eternal beings. Hence Eternity is the second intelligible triad, which brings to birth the autozôn as the third intelligible triad.

What is before Eternity? Eternity is not itself the primal unity of Being, but rather, it is the principle of giving birth. It is the second moment; the power (dunamis) in the triad paterldunamis/nous; the life (zôê) in the triad on/zôel nous; the procession (proodos) in the triad monêlproodos/epistrophê. ${ }^{11}$ As power, life, and procession, Eternity is the principle of emergence, and what emerges is before it. Remember also that not all which is is eternal. Therefore Being must be a principle which is more comprehensive than Eternity, and in Procline metaphysics the higher principle is more comprehensive than the lower. Thus the unity to which Eternity looks is Being itself, and it is Being which Eternity causes to be expressed and brought to birth in multiplicity in the autozôn. Being is the first intelligible triad, called by Proclus the One-Being. Proclus interprets the phrase "Eternity which remains in a One" from Plato's Timaeus to refer to this. The One in which Eternity remains is not the One itself, but rather the unity of the One-Being.

If Eternity manifests a duality, even if we are often silent about this in our haste - for the "always" is bound to "being" (tô $i$ onti) in one unity (kata tauton) and "Eternity" (aiôn) is "that which always is" (bo aei ôn) - it seems that that before Eternity there is the monad of Being, the One-Being, and remaining in this One [i.e. in the One-Being]. (Proclus, In Timaeum III.15.11-15)
The monad of Being is the One-Being, so that it is in this that Eternity remains. Eternity manifests the duality of "being" and "eternal." But the Being which lies before it also manifests a duality: that of "One" and "Being." The One itself as absolute simplicity does not admit of any duality, and so cannot be said to be. But the unity which Eternity makes manifest is a unity of Being, and is therefore the One-Being, not the One itself.

So we see that Being does not fall into eternal and temporal as genera of itself. Rather, Being gives forth through the productive power of Eternity the eternal genera in the autozôon, which themselves give rise to a temporal image. Because Time is an image of Eternity, rather than simply a different mode of existence for beings, we should expect that Time will also be a principle of bringing to birth and of unification. In summary, the three moments of the intelligible in Nous are the simple source which remains in itself, the One-Being; Eternity as the principle which brings to birth the intelligible genera and unifies and comprehends them; and the autozôon which is a living multiplicity of intelligible genera, erotically turned towards the unity which is their source.

\section{Time as a Moving Image of Eternity}

In what manner is Time a moving image of Eternity? Proclus tells us that Eternity measures the intelligible, as a unity, while Time measures the things which are in becoming, as numbered. Eternity is a measure in the sense that the multiplicity of intelligibles in the autozôn are all beings, and as such they are all expressions of the unity which is the One-Being. Eternity is the principle which brings them forth into a permanent existence, and leads them back beyond itself to the One-Being, specifically because they manifest in a multiple form the unity which is the One-Being. It is measure because the eternal multiplicity of intelligible genera strive towards the unity which it reveals while manifesting it in their own multiple way.

Beings which come to be and pass away, on the other hand, do not partake of the permanence of Eternity. They have only an image of that permanence, which we know as duration. Thus the principle which is their measure, the unity which they strive towards and manifest, is not Eternity, but Time.

So in the same manner as the cosmos is said to be an image (eikôn) of the intelligible, so the cosmic measure is named an "image" of the measure of the intelligible. But Eternity is a measure because it is a unity (hôs to hen), while Time is a measure because it is a number Both of them measure, but Eternity measures what is unified, while Time measures what is numbered; Eternity measures the permanence of beings (diamonên tôn ontôn), while Time measures the duration of things which become (paratasin tôn ginomenôn). The supposed 
opposition between them [Eternity and Time] does not indicate $<$ some sort of $>$ dissimilarity between the measures, but rather indicates the derivation of the secondary realities from the older ones. For procession (proodos) derives from remaining (mones) and number derives from unity (tou henos). (Proclus, In Timaeum III.17.25-18.02)

Plato tells us that Time "proceeds according to number" (Plato, Timaeus $37 \mathrm{~d}$ ), and measures things which become as numbered. Proclus contrasts this with Eternity which "remains in a One" and measures things as a unity. Eternity measures things as a unity because that which it measures is an unchanging multiplicity, or rather, a singular multiple reflection of the One-Being. Time, on the other hand, measures things as numbered, because things which come to be and pass away exhibit a diversity of periods, or cyclical activities, which makes up for them their duration. More importantly, their duration is numbered because they do not exist as a whole all at once, and if they are not to be completely without order their duration must be numbered. We should understand "number" here both in the common sense manner, as the number assigned to the periodic orbit of a planet, and in a sense more akin to logos or eidos. In this second sense, Time is the measure of encosmic beings because it is the number or order of their unfolding into multiplicity. Hence it contains the plan both of their unfolding and of their perfection.

Perhaps also Time is an image of Eternity because it is that which brings encosmic beings to perfection, just as Eternity does for [eternal] beings, as "that which holds them together" (sunocheus) and "guardian" (phrouros). ${ }^{12}$ So that things which are unable to live according to nous are brought under the order of Fate (bupo tên tês heimarmenês agetai taxin), lest they flee the divine completely and come to be without order. Thus even that which has departed from Eternity and is unable to partake wholly in the perfection of Rest by remaining always all at once the same (hama kai aei tauta) is perfected through the sovereignty of Time. [Temporal things] are roused by Time into activities (energeias) which are profitable for them, and through certain recurrent periods are able to enjoy the perfection which is appropriate to them. (Proclus, In Timaeum III.18.02-12).

Each thing which is in becoming has its own period, and thus its own numbering of its period, which sets its boundaries and its circuit. In his characterisation of temporal things as periodic, Proclus has in mind primarily the periodic activity of Soul. However, he also has in mind the circular orbits of the planets, whose periodic return to their starting points is an image of the activity of Soul; and the periodic return of things to their point of origin in Nature, such as the seasons, and the procreation of animal species. The circuit of the species oak tree from acorn to maturity and then back to acorn again illustrates how Proclus thinks about this. The oak species has a period in the sense that there is a return to the beginning point in the offspring. This period is numbered because it usually takes a certain number of years. However, it is also numbered in the sense that this period progresses along a certain bound circuit - acorns don't mature into elm trees, for example - and this boundary to the circuit of the life of this species is set according to Proclus by the monad of Time and the species' participation of the Forms in the monad of Time. While this characterisation of Time applies to all encosmic things, we will speak here only of the participation of the Soul in Time. ${ }^{13}$

Time is not only an image of Eternity, it is a moving image of Eternity. However, Proclus points out that nothing can move with regard to the whole of itself, as there must be a subject for movement which remains the same and undergoes the motion. Otherwise there would be a substantial change, and in moving with regard to the whole of itself Time would cease to be Time. Thus the monad of Time is in itself unmoving, and only moves in its participants.

So indeed the monad of Time remains (menei), because it is suspended from the Demiurge, but being filled with measuring power, and wishing to measure the motions of the soul's essence (ousia), and the activities (energeiai) and passions (pathemata) of the physical and bodily, it proceeded according to number. Time, remaining in its own partlessness and internal energeia, with regard to its external [energeia], that which is contained by what is measured by it, proceeds according to number, that is according to certain intellectual eidê, or rather according to the first number itself, which presides over the intellectuals (ta noera), in a manner analogous to the One Being, as Parmenides says, which presides over the intelligibles. Time proceeds then according to that number, on account of which it provides the appropriate measure to each of the species (eidê) of encosmic beings. (Proclus, In Timaeum III.19.02-14)

The monad of Time itself stands above that which it measures, as Eternity stands above the intelligible genera. Notice that in order to be analogous to the intellectual orders, Proclus has distinguished the "first number itself" (auton ton prôtiston arithmon) from the monad of Time. This number is a higher unity than Time, just as the One-Being is a higher unity than Eternity. We can take this as an example of Proclus' idea of the analogous structures which hold between different levels of the universe. As there are higher unities than Time, Time itself not only measures, it is itself measured.

Time itself is also measured, but not by anything extended (for it would be ridiculous to say that that which possesses the elder nature 
and worthiness is measured by that which comes after it). Rather, Time is measured by the single monad of Time, which its procession (proodos) is said to unfold (anelittein), and much more primarily by the Demiurge and by Eternity itself, of which we say it is an image, and with regard to which it is rendered mobile. (Proclus, In Timaeum III.31.04-10)

In other words, just as the intelligible genera unfold Eternity and the One-Being, that which partakes of Time unfolds the monad of Time, and the Demiurge, and Eternity. The term unfold (anelittein) has a technical meaning in Proclus. It refers to the unfolding or unrolling of the higher principle by the lower, by which the higher unity is manifest in the lower multiplicity. All unfoldings are multiple reflections not only of their immediate superiors, but of every analogous order above them. As that which measures, Time is a number. But it is a number in the sense of an intellectual eidos, so it measures its participants because it is an intellectual eidos which its participants unfold.

So Time has various levels. i) It is number as "what is numbered" or measured by itself, i.e. its presence in what participates in Time. ii) It is number as the measure of its participants, i.e. through itself as the monad which is the unmoving moment of Time itself. iii) Finally, Time as a whole is measured by what stands above it: the Demiurge, and Eternity. So Time as number exists in its participants as that which is measured by itself, as itself the measure of its participants, and as itself being measured by higher principles.

Proclus tells us that Time proceeds according to a number which is the intelligible number, referring either to the autozôon, Eternity, or the intelligible as a whole. However, when Timaeus says that Time proceeds according to number, he is referring primarily to Time itself as the intellectual number which numbers or measures the simple procession of Time and the complex procession of things in Time. ${ }^{14}$

So Time does proceed according to the intelligible number, and also in that it itself numbers its participants, and also again it proceeds according to the number in its participants by which they are numbered. This [last] is [Time as] numbered, and possesses only a sort of image (eidôlon ti) of essential Time (ousiôdous chronou), by which everything is numbered through the larger or smaller numbers of their own life, so that a cow lives for a certain time, a man for a certain time, and the sun, the moon, Saturn, and the other planets have their return and make their periodic revolutions by this or that measure. (Proclus, In Timaeum III.19.24-32)

It is this middle sort of measure, Time as the measure of its participants, which is important for us here.
Time measures the duration of the life of its participants. More importantly, Time measures their circular activity, most prominently the orbits of the planets, and the circular activity of the soul of the cosmos and partial souls. ${ }^{15}$ Time brings itself to imitate Eternity, because as Eternity is comprehensive of the intelligible genera, Time is comprehensive of its participants. But it also brings temporal things themselves into a closer imitation of the intelligibles. Things in Time do not share in the permanence and unchanging identity of the intelligibles, but through their circular revolutions and periodic returns to their beginning points they imitate this intelligible immobile permanence (Proclus, In Timaeum III.20.00-21.05). Circular motion is in one sense motion, but in another sense it is a being at rest, because what is in motion always returns to its point of origin. In a certain sense, moreover, circular motion has no beginning point. One might think of a planet as desiring the rest of the centre of the circle which is its orbit, but being unable to attain that rest, it imitates it by its unbroken circling motion. By contrast, rectilinear motion leaves its point of departure never to approach it again. However, Time also embraces rectilinear motion, because even that which is below things which move in a circle are measured by their duration. For this reason Proclus says that Time is said to move in a spiral (belikoeidê), because the spiral embraces in one single Form both the circular and the rectilinear (Proclus, In Timaeum III.21.02-05).

This measurement of the periodic energeiai of things is the primary sense of Time for Proclus. Time perfects things, and brings them to imitate the intelligible paradigms by measuring their periodic revolution around itself. Proclus does concede that we have another sort of measurement of Time, in our marking of the passage of Time. But the sort of measuring which we do, and which we normally consider to be Time in the primary sense, is performed with a certain notion (ennoia) which is only "about" Time and is not Time itself (touta gar hê ennoia drâi hê peri chronou kai ouk autos ho chronos) (Proclus, In Timaeum III.20.02-03). If Time is to be the measure of our motion, it certainly could not be an ennoia which is in us. Even the motions of the heavenly bodies, which we think of as marking Time, are not the primary measure, because they themselves are also measured. They have determinate periods to their circular energeiai. The primary measure must be the monad of Time itself, which is a moving image of Eternity. "Image" because it embraces its participants with its number in the way Eternity embraces the intelligibles with its unity, and "moving" because its participants are in motion, although it itself is at rest.

\section{Time as Nous}

What is the monad of Time itself and how does it measure the circular activity of the Soul? According to Proclus, it is a nous which is unfolded and 
unrolled by the activity of things in Time, but primarily by the dianoetic activity of the Soul.

For as Nous is to the Soul, so is Eternity to Time, and inversely, so that Time is before the Soul, just as Eternity is before Nous. And Time should be participated by the Soul, and does not participate in the Soul, just as Nous does not participate in Eternity, but the inverse. So Time possesses a certain intellectual nature (noeran ... tina phusin) which moves in a circle everything which participates in it, and particularly souls. (Proclus, In Timaeum III.27.20-26)

Time is an intellectual nous (nous noeros), i.e. a nous in the intellectual hebdomad of Nous as a whole situated below the Demiurge.

According to Proclus the essence (ousia) of the soul is a fullness of logoi (plêroma tôn ousiôdôn logôn) which are the soul's participation in Nous. However, the soul is not immediately conscious of its own essential logoi, and possesses them as if breathing, or like a heartbeat. ${ }^{16}$ In order to make this hidden content of its own ousia explicit to itself, the soul must draw them forth through what Proclus calls projection (probolê). But because the soul is not able to grasp the entire intelligible world in one simple act, it cannot draw forth all of its logoi at once. Rather, it draws them forth one at a time in the divided motion which is discursive thinking (dianoia). Thus the divided motion of dianoia is what is measured by the monad of Time.

Because the logoi which constitute the Soul's ousia are its own participation in Nous, the dianoetic activity of Soul as an unfolding of its own ousia is also an unfolding of Nous itself. And because the particular Nous which the Soul unfolds is the monad of Time, this is the sense in which Time is a measure of the Soul's activity. The Soul unfolds and unrolls the nous which is the monad of Time, through a thinking activity which may be understood metaphorically as a circle, circuit, or period which has Time as its centre.

And so, Time is eternal, and a monad, and a centre by its essence and its activity which has remained at rest in itself; and at the same time it is continuous, and is a number, and a circle by its procession and what participates in it. [Time] then is a certain proceeding nous, since it could not bring to perfection the resemblance of encosmic beings to their paradigms unless it itself were first suspended from [these paradigms], but it also proceeds and flows en masse towards the things (ta pragmata) over which it keeps guard. (Proclus, In Timaeum III.26.30-27.08)

The Soul partakes of Time, but not in its ousia. Rather, it is the changing energeia of Soul which participates in Time. The Soul unfolds its own unchanging ousia, but this ousia participates in Nous atemporally. It is only in the activity of unrolling and unfolding its own ousia, through the projection of the logoi which are its ousia (probolê tôn ousdiôdôn logôn), that the Soul participates in Time. Why not identify the monad of Time with the ousia of the Soul? This is a complex issue, and amounts to the question "why is the ousia of the Soul not itself Nous?" The answer is likely that the Soul's ousia is not identical to Nous, but rather is a remaining in Nous, because Nous is the Soul's point of departure and that towards which its energeia strives in its return. We must resist thinking of ousia, dunamis, and energeia as three absolutely separate things. They are moments of the unfolding of Soul as a whole. So the ousia of the Soul is not identical to Nous in the same manner in which the point of departure is not identical to the first leg of a journey.

Time is at rest both in its ousia and its energeia while the Soul is at rest only in its ousia, and in motion in its energeia. However, Time proceeds in its participants, so the description of Time as at rest has to be understood in such a way that in itself Time is at rest, both in its ousia and its internal energeia, but is also in motion in its participants, or in its external energeia. ${ }^{17}$ Being at rest and being eternal are identified in Proclus, so both Time and the ousia of the Soul are eternal. As well, Time's presence in its participants and its external energeia must be identified. If we take the three terms - ousia, internal energeia, and external energeia - we are able to rank Eternity, Time, and the Soul with regard to a greater and greater share in motion. Eternity is at rest in its ousia, internal energeia, and external energeia. Time as Nous is at rest in its ousia, and its internal energeia, but it is in motion in its external energeia, i.e. in its participants. The Soul, on the other hand, remains in Nous, and so is said to have an ousia which is at rest and eternal. Yet neither its internal nor external energeia is at rest (Proclus, In Timaeum III.24.02ff; 25.11ff).

Proclus describes the energeia of the Soul as a circle, circuit, or period around the centre which is Time. The circle metaphor is extremely important for Proclus, because it is his primary metaphor for describing the relation between dianoia and Nous. It may be thought of in two complementary ways. In one way of thinking, Nous is a point in which the Soul remains, and from which its activity begins. This activity circles forth, unrolls the concentrated content of Nous, and returns back to its beginning point in Nous at the end of its period. This point of view is used by Proclus when speaking about the generation of a lower spiritual entity by a higher, because it emphasises the aspect of remaining in, proceeding from, but returning to a given cause. However, in the context of the Soul's circuit around the monad of Time the complementary point of view is more important. Rather than an original point on the circumference of the circle which is the Soul's activity, Nous, as Time, is the centre of the circle, and the Soul's activity is the circumference. The distance of the circumference from the centre indicates that the Soul has proceeded from Nous. And the orientation of the circumference around the centre indicates the circling 
return by which the Soul tries to attain the unity of Nous, but makes itself many in its own thinking. The Soul circles around Nous, viewing it from different sides, and it is the various points of view which constitute the divided logoi which are the conceptions of the Soul's dianoia.

And so the procession of Time is a dividing and unfolding motion [kinêsis] which makes appear part by part the power which remains partless, like a sort of number which receives in a divided manner all of the eidê of the monad and which returns back towards itself and

begins the circle anew. (Proclus, In Timaeum III.30.26-30)

The motion of Time, i.e. this dividing energeia of Soul which participates in Time, is measured by the Monad of Time, and even higher, by the Demiurge, and by Eternity. The sense of measure becomes clear here. These higher unities are a measure in the sense that they are the paradigm which the divided image in the thought of Soul seeks to reflect. They measure, because the term of the Soul's period, its metaphorical circuit or circumference, is oriented back towards an explication of the centre which is Nous. They measure, because they are the comprehensive source, and the originary touchstone for the divided energeia which is the activity of Soul.

Proclus states that the monad of Time and the dianoetic activity of the Soul which unfolds it is an image of Eternity and the intelligible genera in the autozôon. It is extremely important to take this statement seriously. Just like Eternity, Time is a principle of bringing to birth, or dynamic coming forth. It is a principle which divides up the unity of Nous and gives rise to the dynamic energeia which is the periodic motion of the Soul. Eternity gives rise to multiplicity as simultaneous presence. Time, on the other hand, gives rise to serial motion. We as souls do not have the entirety of the intelligible eidê present to our minds. Rather, we strive erotically towards them through a divided thinking which sees them dimly, part by part. So while Eternity and Time are both principles of bringing forth multiplicity, of giving birth to a multiple image of a prior unity, they themselves differ from each other as paradigm and image. The whole of Eternity is present to the intelligibles, and so is the whole of Time present to its participants, but while Eternity is present to the autozôon all at once, Time is broken up in its participants into what Proclus calls the eide of Time: was, is, and will be (Proclus, In Timaeum III.37.01; 50.22-51.22). This difference is expressed in a lovely way even in the names for Eternity and Time, according to Proclus. Eternity (Aiôna) is to aei einai, i.e. the being which always is; while Time (chronos) is choronous, i.e. the Nous which dances in a circle like the chorus (Proclus, In Timaeum III.9.16-18; 28.00).

Moreover, both Eternity and Time are principles not only of bringing to birth, but of unification. The intelligible genera in the autozôon are not simply a random collection of Forms. Rather, they are a complete totality of living Forms which are unified as a single reflection of the unity of the
One-Being. The logoi which the Soul projects, as long as its self-motion (autokinêsis) is not infected with the motion-from-without (beterokinêsis that arises from body, are not simply random thoughts about this or that. They are multiple, and in that sense are a descent from the unity of Nous. However, they are each of them vectors back towards the Nous which is the centre of their life. Hence the unfolding of logoi in dianoia allows the Sou eventually to leave behind dianoia by making more and more clear the Soul itself as image, and in doing so point more clearly the way towards Nous as the paradigm.

But as long as our thinking remains dianoia without passing over into Nous it will seek wholeness without achieving it. Jean Trouillard speaks of the philosophy of Plotinus, but his characterisation is equally true of the Procline conception of dianoia.

Nous does not infuse Soul with Ideas, but rather, through the irradiation of the intelligible and the sight which the soul directs towards Nous, we beget notions and logoi [raisons]. ${ }^{18}$

The birth of these logoi will not cease until we leave behind dianoia altogether.

\section{Conclusion}

The consequences of this conception of dianoia for Proclus' systematic philosophy cannot be ignored. Being and thought for Proclus are dynamic, from the highest to the lowest levels of Being. His system traces the motion of a single power which begins from absolute unity and divides itself in a dynamic remaining, procession, and return. In this process Being itself is articulated, and brought to birth. Each successive level is the same as its prior insofar as it is similar and an image, but it must be admitted that as image it is also different from and other than that of which it is an image.

This puts into question the status of the divided logoi which dianoia employs to construct a systematic philosophy that strives to embrace all levels of reality. Proclus is quite explicit that like is known by like. Sense knows the sensible, opinion the opinable, dianoia the dianoetic object, Nous the intelligible object, and it is by a one that we unify with the One (Proclus, Theologia Platonica I.15.17-21). In many of his writings Proclus indicates that he thinks the partial soul can leave behind its divided activity and rise to the level of Nous, and even the One. ${ }^{19}$ Even if this is true, that which is known by dianoia is known in a divided manner. Further, any transcendent experience of Nous, if it is to be expressed to others or to oneself in a philosophical system, must be expressed in the language of dianoia - in one's own thinking, in speech, or in writing. ${ }^{20}$ So when we assess the writings of Proclus as philosophical system, we must not forget that they are a record of a thinking which is dianoia. 
As we have seen from this study, Proclus thinks that dianoia is a circling around a centre which is its own participation in Nous. Thus it seems to have a number of characteristics which affect its status as systematic philosophy. The first is the fact that at any given time it is incomplete. The unity of the One-Being is present to the autozôon through the mediation of Eternity in a simple presence. But dianoia is always still on the way. The intelligible is present to it only through its own dividing circuit of Nous, and this circuit in fact is never finished on the level of dianoia. This circuit is never finished for dianoia because dianoia is a circumference which never touches the centre which it explicates. In like manner, the One-Being stands aloof from the intelligible multiplicity of the autozôn which reflects it. As long as the Soul persists in an activity which divides the unity of its participation in Nous, it produces for itself dianoetic logoi instead of intelligible eidê. Thus the period of the Soul's activity will never be finished until the Soul leaves behind the dividing activity of dianoia, and flees multiplicity for the quiet unity of Nous. But then such a Soul would have ceased to engage at all in philosophy. Moreover, the dividing activity which is dianoia brings into existence a level of being which actually differs from its paradigm, even if it is an image of it. All that is in Time exists because of the declension in being to which the divided activity of Soul gives rise. So in a certain sense, dianoia is a discourse which in speaking brings the terms which it uses into being. This should make us wary of the status of systematic philosophy's claim to comprehend all of reality, as the terms in which it must necessarily deal exist only on the psychic level, and refer to what lies above them only as images refer to their paradigms. ${ }^{21}$

Thus any claim such as Lowry's, that Proclus' system seeks to be complete, comprehensive, or a totality, is a misreading of Proclus' system. Systematic philosophy, for Proclus, is in principle incomplete, because the logoi in which it is expressed will in principle never finish their explication of Nous. The articulation of points around the centre of a circle may never end, because there are a potential infinity of perspectives on the circumference from which to view the centre. Because systematic philosophy is in principle incomplete, each philosophical work must be thought of as a partial explication of Nous. Finally, the divided language in which systematic philosophy expresses itself is brought into existence by dianoia itself, so any set of principles or propositions which constitute a philosophical system must be thought of as a divided image of undivided Being, rather than a comprehensive account of the articulations of Being itself.

Let us take it as established, then, that Proclus thinks systematic philosophy speaks its own dianoetic language. He also thinks that this is not the only language in which one may speak of the gods. One may speak like the priests, who under divine inspiration name the gods according to the fashion of their sect; or one may speak symbolically or mythologically, naming the gods by their Greek mythological names; or one may use mathematical images of the gods, as do the Pythagoreans (Proclus, In Parmenidem 646-647; Theologia Platonica I.17.9-23.11). It must be granted that Proclus describes the dianoetic mode of exposition in certain places very much in the manner that Lowry puts forth (Proclus, Theologia Platonica I.20.19-25). But it remains the case that dianoia divides its object and so in understanding what lies above it, dianoia makes it what in a certain sense it is not. If this were not the case, then there would be no need for the symbolic, enthusiastic, or mathematical modes of divine exposition. Further, the end of dianoia would be dianoia itself. And from Proclus it is fairly clear that the end of dianoia is Nous and unification with the One.

So it seems to be the case that Lowry is misreading Proclus. It remains possible that Proclus should take Lowry's advice by discarding the One and Nous, and embraced the All as dianoetic. Proclus would likely respond to this suggestion in the following manner. Dianoia is a dividing activity, which has as its end a comprehensive grasp of what it divides. But if there is no original unity from which dianoia takes its birth, then what is dianoia dividing? Dianoia cannot divide itself, as a dividing activity cannot itself be divided; it requires something other than itself on which to work. Further dianoia is erotic. It is drawn towards its object. If its object is itself, is it not then already in possession of what it seeks? And if so, would not erôs disappear? Finally, if dianoia makes its own world in thinking, upon what model is it basing its images? What measures its motion, and keeps it within the boundaries of the true, even if that truth is dianoetic truth?

I began with a preliminary taste of the extant Procline corpus. What should we make of its two systems, five Platonic commentaries, mathematical, physical, and moral works? I suggest that the corpus of Proclus is a projection which is underway. If we were to consider it complete, either in one of its parts or in toto, we would have to hold that Proclus himself was able to complete his periodic revolution around Nous, and moreover, that he was able to express this secret noetic content in dianoetic terms. Instead, the Procline characterisation of dianoia should make us realise that his philosophical corpus is a series of divided approaches to intelligible unity. Moreover, in bringing these works into being, the dividing thought which is dianoia simultaneously brings into being the philosophical terms which it employs. But this dividing activity can never exhaust its source. Philosophical reason in principle cannot cease to articulate anew the unity around which it circles. So the aim is not completion, if completion means finality. Rather, for Proclus philosophy as system should be thought of as a series of vectors, which point the dividing mind back towards the unity which it divides.

I finish with Jean Trouillard once again, on Plotinus.

We will always be stuck if we want to understand the Platonic or Plotinian Ideas as structures which we posit outside of us. Thrown 
before us in this way, they will lose the character of concrete presence which we can not deny them. They will be categories, postulates or myths. They can not be constructed, or given. It remains that they are norms which are "seen" and achieved, and are identical to the activity of Nous, which the whole life of the soul makes use of but never equals. This is why you could extend the list of the Ideas without end, but miss the essential point. Plato himself only gave examples. Those who today have wished to attempt it have produced a deceptive and empty result. ${ }^{22}$

\section{Notes}

1 For two glimpses of this contribution see Gersh 1978; Hankey 1980

2 There has come to be an extensive literature on Proclus, most of it in the form of articles rather than monographs. The main bibliography for this literature is Muth 1993. The three most important monographs on Proclus are Trouillard 1972, Beierwaltes 1965, and Gersh 1973.

3 See for example Proclus, In Euclidem 3-5.

4 Lowry 1980, 85. The disagreement between a Procline and an Hegelian philosophy over whether the first principle should be self-thinking thought or the One is related to the disagreement about the nature of philosophical system itself. In Proclus the multiplicity of system is an expression of a prior unity which cannot be grasped on its own terms. Thinking creates its own categorie in an attempt to explicate its source which both succeeds and fails. Hence the most proper name for the first principle of all is the One, because this name is the best symbol for the hidden and unspeakable unity that is the pole around which the multiple articulates itself. This is different from a philosophy in which which the multiple articulates itself. This is different from a philosophy in which

the movement is the self-articulation of the first principle itself, as in Hegel.

5 Lowry is in fact referring to the henades huperousioi, not the henades which are the intelligibles in the autozôon and which are the genera of Being. His reading is again an Hegelianising reading, in which it would be natural to think of the first unities as beings. But for Proclus that which is multiple in principle comes before that which is multiple as determined. And so between the One and the intelligible genera come the first Limit, the first Unlimited, and the henads.

6 He speaks of triads because each is a triad of remaining, proceeding, and returning moments, which are the ubiquitous structuring principles of the Procline cosmos.

7 That there is a seven-fold division of the intellectual order indicates that Proclus is not following only the inner logic of dianoia. He most often does follow this logic, and his system usully unfolds in triads. But the intellectual hebdow logic, and his system the in likely drawn from the Chaldaean Oracles, which Proclus considers to be a higher revelation of the hidden secrets of divinity than dianoia. See Lewy 1978 and Festugière 1971

8 See the discussion of the mixture of Forms at Proclus, In Parmenidem 768ff.

9 This dynamic coming forth of a multiplicity from a previous unity is forceably stated by J. Trouillard. See Trouillard 1960, 86: "Le genre n'est pas seulement la raison efficace des ressemblances, mais aussi de l'infinie diversification des espèces et des individus. Car par l'apeiron qu'il contient uni à son peras il peut alimenter dans une ligne donnée les antithèses mutuelles des termes subordonnés. Et cette synthèse d'autre et de même forme la série appropriée ou le nombre connaturel à chaque unité qualifiée... Cela ne signifie nullement que le genre soit le genre soit ce qu'il produit en ce sense qu'il enfermerait d'avance l'idée distincte de ses participations. Celles-ci peuvent lui ressembler sans que lui leur ressemble. Il faudrait plutôt dire qu'il les fonde selon tout leur être, parce qu'il a en lui beaucoup plus qu'il ne faut pour justifier leur apparition ..." See also Gersh 1973, 120-121.

10 Richard Sorabji, in Sorabji 1983, 137-156 makes a case for the position that the thought of Nous in Plotinus is propositional. His argument is that where there is complexity of thought, there is predication. I do not find this convincing, for the following reasons. First, in the contemporary analytical context out of which Sorabji writes, propositional thought connotes more than complexity. It is usually understood, whether tacitly or explicitly, to involve a synthesis of terms. As I am arguing, in Neoplatonism thinking is not a synthesis, but rather division of a prior unity. Hence the Kantian demand for a justification of a priori division of a prior in synthetic propositions is mio unity which alows in the first place. Further, for the position that the thought of Nous is propositional as a whole, including the intellectual moment, to have any real content it is necessary that there be a real difference between subject and predicate. Thus Nous would think a Form by thinking that it is something, and this something must be something else than the original Form if all of Nous' thoughts are not to be analytic. But what would Nous think the Forms are other than themselves? Why is the conception that all of Nous' thoughts are of the form " $\mathrm{X}$ is X" more attractive than the conception that Nous' thought is a non-propositional resting in itself. Finally, a proposition implies logical motion from the subject to the predicate, mediated by being. The mind moves from the concept of the subject, through the concept of being, to the concept of the predicate. The motion in Nous seems much more to be a unified splintering of Being itself which produces its own determinations, which then can stand as subjects and predicates for discursive thinking. Propositional thought is not such as to give rise to the original genera of Being, but the thought of Nous does in fact do this, according to Plotinus and Proclus. For this reason I think Sorabji is mistaken in calling the thought of Nous in Plotinus propositional.

11 Proclus, In Timaeum III.10.30; 15.11-15. These three triads are: father/power/ intellect; being/life/intellect; remaining/procession/return. Each triad is each of these three sets of moments. However, the structure is repeated on a higher level, these three sets of moments. Howerer, the structure is repeated on a higher level, so that the three intelligible triads themselves may be thought to follow these
sets of moments.

12 For these two Chaldaean terms Festugière refers us to Lewy 1978, 129-131.

13 See Beierwaltes 1965, 196-200.

14 The procession of Time considered as a whole is a simple, undifferentiated, and regular motion, even if the procession of its participants is complex, differentiated and irregular motion. See Proclus, In Timaeum III.30.11ff.

15 The partial soul is the soul which animates a human body. It is called partial (merikê) because although on the one hand it can be considered an individual and a soul in its own right, on the other hand it is a part of and an image of the hypostasis of Soul as a whole. Both Nous and Soul as hypostases are such unified multiplicities in which the structure of the whole is mirrored in each part.

16 Proclus, In Alcibiadem 189.6-11; 192.2-5. See also C. Steel 1997.

17 Proclus, In Timaeum III.27.26-32. For a discussion of internal and external energeia in Plotinus, see Gerson 1993, 566ff. 
18 Trouillard 1956, 70: “L'esprit n'infuse à l'âme aucune idée, mais, par l'irradiation de l'intelligible et la visée que l'âme dirige vers lui, nous engendrons notions et raisons."

19 See Proclus, In Parmenidem 74K in the edition of Steel, Rumbach, MacIsaac 1997, lines 687-698.

20 The status of speech and writing are of course controversial. For Proclus, they would be a divided image of dianoetic thought, analogous to the manner in which dianoia is a divided image of Nous.

21 See the discussion of analogia in Gersh 1973, 83-90.

22 Trouillard 1956, 71: "On échouera toujours tant qu'on voudra réaliser les idées platoniciennes ou plotiniennes come des structures que l'on pose devant soi Ainsi projetées, elles perderont le caractère de présence concrète qu'on ne peut leur refuser. Elles seront des catégories, postulats ou des mythes. Elles ne peuvent être ni construites ni données. Reste qu'elles soient des normes apercevantes et réalisantes, identiques ấ 'activite de l'esprit, que toute la vie de l'âme emploie sans jama d'étendre d'étendre sans fin en laissant échapper l'essentiel. Plato n'en a donné que des exemples. Et, de nos jours, ceux qui ont voulu s'y essayer ont fait un travail caduc at décevant."

\section{References}

Beierwaltes, W. 1965. Proklos, Grundzüge seiner Metaphysik. Frankfurt a. M.: Klostermann.

Festugière, A.J. 1971. "Contemplation philosophique et art théurgique chez Proclus." Ettudes de philosophie Grecque. Paris: Vrin, pp. 585-596.

Gersh, S. 1973. KINESIS AKINETOS, a study of spiritual motion in the philosophy of Proclus. Leiden: E.J. Brill.

-. 1978. From Iamblichus to Eriugena, and investigation of the prehistory and evolution of the Pseudo-Dionysian tradition. Leiden: E.J. Brill.

Gerson, L. 1993. "Plotinus's metaphysics: emanation or creation?" Review of Metaphysics 46, pp. 559-574.

Hankey, W.J. 1980. “Aquinas' first principle: Being or Unity?" Dionysius 4, pp. 133-172.

Lewy, H. 1978. Chaldaean Oracles and Theurgy, Mysticism, Magic and Platonism in the Later Roman Empire. Cairo (New edition with a contribution by P. Hadot, "Bilan et perspectives sur les Oracles Chaldaïques et une bibliographie de H. Lewy." Paris, 1978)

Lowry, J. 1980. The Logical Principles of Proclus' Stoicheiôsis Theologikê as Systematic Ground of the Cosmos. Amsterdam: Rodopi.

Muth, N.S. 1993. Proclo, negli ultimi quarant' anni, Bibliografia ragionata delle letteratura primaria e secondaria riguardante il pensiero procliano e $i$ suo influssi storici (anni 1949-1992). Milano: Gemelli.

Plato. 1972. Timaeus. Edited by I. Burnet. Oxford: Clarendon Press.

Plotinus. 1984. Ennead V. Translated by A.H. Armstrong. Cambridge: Harvard University Press (Loeb Classical Library).

Proclus. 1864. In Platonis Parmenidem. Edited by V. Cousin, in Procli philosophi Platonici opera inedita. Paris: Durand (repr. Hildesheim: Olms, 1961).

- 1873. Procli Diadochi in primum Euclidis elementorum librum commentarii. Edited by G. Friedlein. Leipzig: Teubner

- 1903-1906. Procli Diadochi in Platonis Timaeum commentaria. Edited by E. Diehl, Vol. 1-3. Leipzig: Teubner (repr. Amsterdam: Hakkert, 1965).
—. 1966-1968. Commentaire sur le Timée. Translated by A.J. Festugière, Vol. 1-5. Paris: Vrin.

- 1968-1997. Théologie platonicienne. Edited and translated by H.D. Saffrey and L.G. Westerink, Vols. 1-6. Paris: Belles Lettres.

- 1985-1986. Sur le premier Alcibiade de Platon. Edited and translated by A. Segonds, Vol. 1-2. Paris: Belles Lettres.

- 1987. Proclus' Commentary on Plato's Parmenides. Translated by Glenn R. Morrow and John M. Dillon. Princeton: Princeton University Press.

- 1992. A Commentary on the first book of Euclid's Elements. Translated by Glenn R. Morrow. Princeton: Princeton University Press.

Siorvanes, Lucas. Proclus. Edinburgh: Edinburgh University Press 1995.

Sorabji, R. 1983. Time, creation and the continuum, theories in antiquity and the early middle ages. Ithaca: Cornell University Press.

Steel, C. 1997. "Breathing thought: Proclus on the innate knowledge of the soul," in The perennial tradition of Neoplatonism, edited by J. Cleary. Leuven: Leuven The perennial tradition of Neopla
University Press, pp. 293-309.

Steel, C., Rumbach, F., and MacIsaac, G. 1997. "The Final Section of Proclus' Commentary on the Parmenides. A Greek Retroversion of the Latin Translation," Documenti e Studi Sulla Tradizione Filosofica Medievale 8, pp. 211-267.

Trouillard, J. 1956. "La médiation du verbe selon Plotin," Revue Philosophique 146 , pp. 65-73.

- 1960. "L'Intelligibilité Proclusienne," in La Philosophie et ses Problemes, Recueil d'études de doctrine de d'histoire. Paris: Emmanuel Vitte, pp. 83-97.

—. 1972. L'Un et l'âme selon Proclos. Paris: Belles Lettres. 


\section{MEDIEVAL PHILOSOPHY AND THE CLASSICAL TRADITION}

In Islam, Judaism and Christianity

Edited by

John Inglis 
First Published in 2002

by Curzon Press

Richmond, Surrey

http://www.curzonpress.co.uk

Editorial Matter (C) 2002 John Inglis

Typeset in Sabon by LaserScript Ltd, Mitcham, Surrey

Printed and bound in Great Britain by IBT Global, London

All rights reserved. No part of this book may be reprinted or reproduced or utilised in any form or by any electronic, mechanical, or other means, now known or hereafter invented, including photocopying and recording, or in any information storage or retrieval system, without permission in writing from the publishers.

British Library Cataloguing in Publication Data

A catalogue record of this book is available from the British Library

Library of Congress Cataloguing in Publication Data

A catalogue record for this book has been requested

ISBN 0-7007-1469-3

\section{Contents}

Notes on Contributors

Acknowledgments

Introduction: Towards a Balanced Historiography of Medieval Philosophy

John Inglis

\section{Section One: Historical Context}

1 Medieval Islamic Philosophy and the Classical Tradition Michael E. Marmura

Section Two: Philosophy

2 A Philosophical Odyssey: Ghazzâlî's Intentions of the Philosophers

Gabriel Said Reynolds

3 The Relationship between Averroes and al-Ghazāii: as it presents itself in Averroes' Early Writings, especially in his Commentary on al-Ghazālī's al-Mustașfā Frank Griffel

4 Al-Ghazali and Halevi on Philosophy and the Philosophers Barry S. Kogan

Section Three: Neoplatonism

5 Projection and Time in Proclus D. Gregory MacIsaac

6 Forms of Knowledge in the Arabic Plotinus Peter Adamson 